\title{
HIGH-TECH EMPLOYMENT AND STATE ECONOMIC DEVELOPMENT POLICIES
}

\author{
Mark Partridge*
}

\begin{abstract}
States have attempted to attract industries by offering a variety of tax incentives and economic development programs with mixed success. States have recently begun to focus on high-tech industries, where average wages are significantly above the all industry average. This study analyzes whether a state's tax and expenditure mix can influence high-tech industry location. Empirically, this study advances previous high-tech research by carefully modelling the govemment budget constraint and by considering more recent data. One emphasis will be whether rural states are inherently unable to attract high-tech industry and its high-paying jobs. In general, the empirical results suggest that a state's fiscal policies can attract high-tech firms, but states must proceed very cautiously. Furthermore, rural states are not dealt out of the high-tech game.
\end{abstract}

\section{INTRODUCTION}

State governments have actively sought to attract new businesses to their states with a myriad of tax breaks and other policies, but it is unclear whether these policies are worthwhile (Wasylenko 1991). One major problem is that the expense of these policies may outweigh the benefits from additional employment.

Many states have changed their focus from a shotgun approach to an emphasis on the better paying, high-tech sector (HT). In essence, states may be adopting their own version of an industrial policy designed to increase the share of "good" jobs (e.g., see Lee 1992; Blakely 1989; Fosler 1988). For example, 21 state legislatures planned to consider HT promotion in 1992 (Schellhardt 1992). The typical HT manufacturing worker earns 54 percent higher weekly wages than his or her private sector counterparts and receives 34 percent higher wages than his or her other manufacturing counterparts (U.S. Dept. of Labor 1991). Furthermore, average wage levels for all industries are positively related to the proportion of a state's jobs that are in higher paying industries because of a demonstration effect (Treyz 1991). These positive wage spillovers illustrate another reason to attract HT industries. Finally, a potential North American free trade agreement will likely result in the contraction of low-tech industries, where intemationally competitive HT industries can fill the void.

\footnotetext{
*Assistant Professor of Finance and Economics, Georgia Southern University. I thank Doug Dalenberg, Jamie Partridge, and the anonymous referees for their useful comments. This research was supported by a University of Montana summer grant.
} 
The determinants of HT firm location are not clearly understood by govemment policymakers. Conventional wisdom is that HT firms' location decisions are more influenced by quality of life and by the skills of the local labor force than by transportation costs (Rees and Stafford 1986; Armington 1986). The effectiveness of traditional state and local tax incentives are ambiguous and signify the need to discover if govemment expenditures can be used to encourage these industries. This study will examine the effect of state and local tax and expenditure policies on the location of HT manufacturing. ${ }^{1}$

This study advances previous HT location studies (e.g., Rees and Stafford 1986; Armington 1986; Malecki 1989; Office of Technology Assessment 1984) by carefully considering both taxes and expenditures within the government budget constraint. By considering the government budget constraint, the empirical modelling explicitly recognizes that if total expenditures rise by $\$ 1$, total revenues must rise by $\$ 1$ (and vice versa). In addition, HT employment equations are estimated alongside equations for more aggregate levels of employment. The two sets of results will be compared to help detect whether government policies have a different influence on the HT sector. (Wasylenko and McGuire [1985] also estimated employment equations for different sectors, e.g., manufacturing and retail trade.) Moreover, state fixed effects are considered by using first differences. Finally, by using 1965-1989 data, the study considers a time period long enough to allow firms to locate in the most desirable location. By considering the 1980 s, this study updates previous HT research that emphasized the mid-1970s.

The outline of the paper is as follows. Section II examines the determinants of HT location. Section III discusses the empirical model and data. Section IV presents the empirical results, and the final section contains some concluding thoughts.

\section{HT LOCATION DETERMINANTS}

Figures 1 and 2 show the intensity of 1965 and 1989 HT manufacturing as a share of total employment for the contiguous 48 states. $^{2}$ I consider a state to be high (low) intensity when its HT share of the total labor force is among the top (bottom) 12 states. In 1965, HT manufacturing was concentrated in New England, the Great Lakes, and Califormia. Low-intensity states were centered in the rural West. Figure 2 shows that New England continued to have one of the highest concentrations of HT employment in 1989, but HT employment concentrations shifted west from the Great Lakes. Low HT intensities have shifted from the rural West to the South. (Park and Lewis [1991] also find a pattern of HT firm dispersion.) The figures suggest that the location of HT manufacturing is very dynamic 
FIGURE 1

1965 High-Tech Intensity HT Manufacturing Share of Total Employment

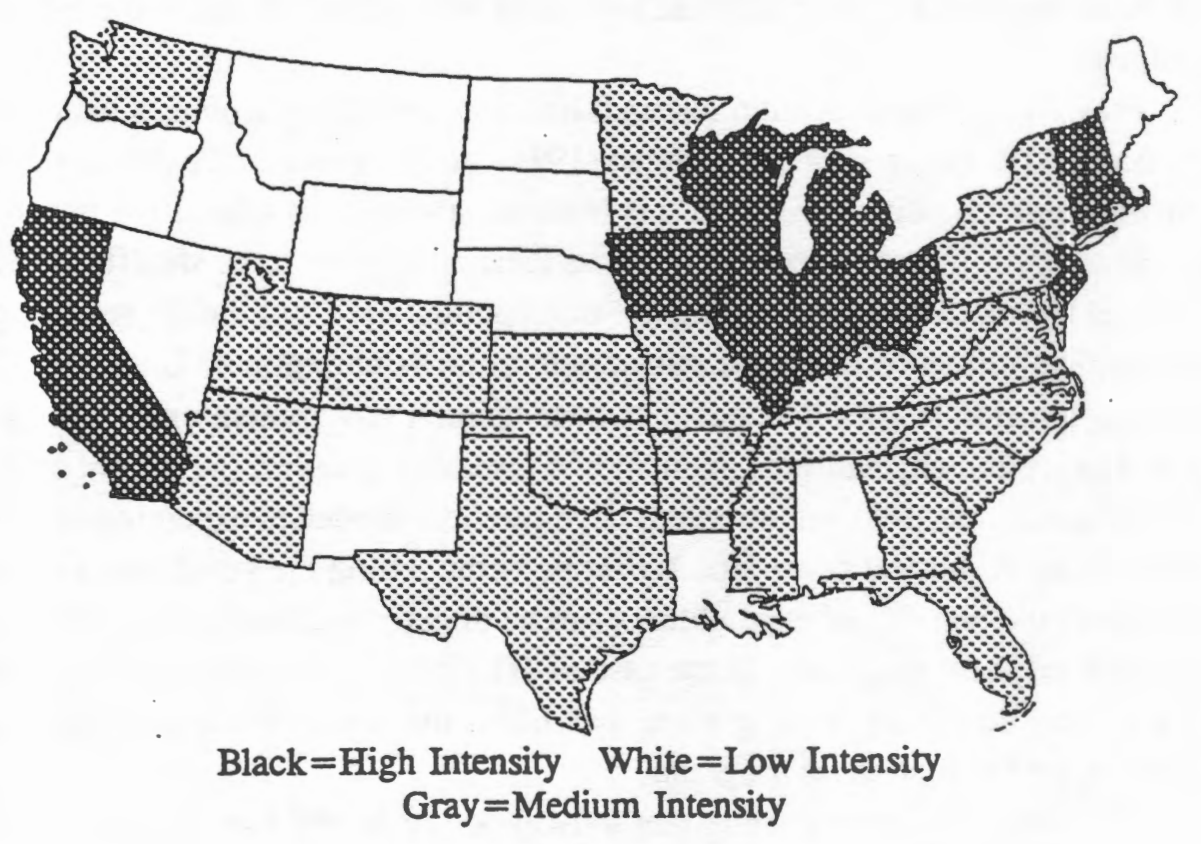

FIGURE 2

1989 High-Tech Intensity HT Manufacturing Share of Total Employment

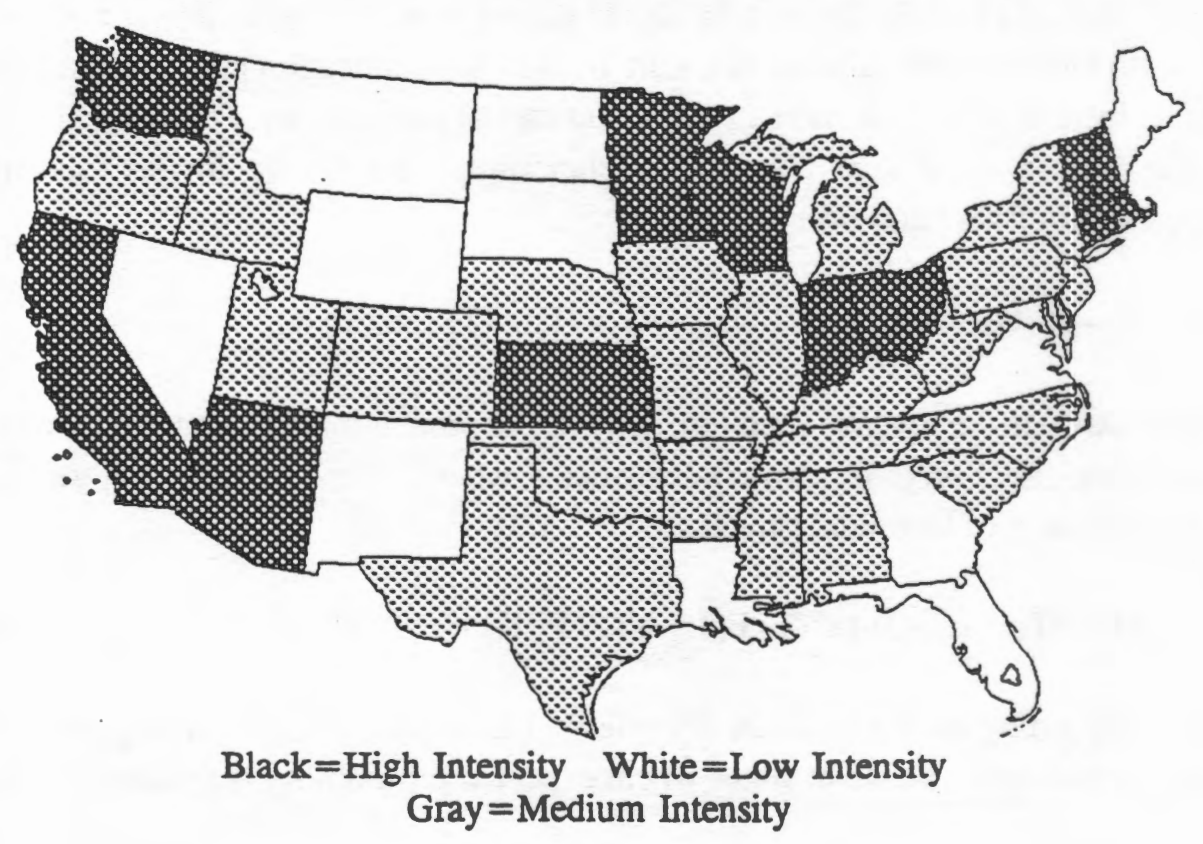


and is consistent with the following two points. First, HT industries are not firmly entrenched, indicating that policies designed to attract these industries may succeed. Second, HT firm movement is consistent with product cycle models where HT firms dispersed from California to nearby West Coast states as the industry matured.

Previous business location research has emphasized taxation as a major factor. Bartik (1991), Gerking and Morgan (1991), and Newman and Sullivan (1988) provide comprehensive surveys of this literature and discuss alternative empirical methodologies. Intrametropolitan business location appears to be significantly influenced by tax differentials within the metropolitan area, but the degree that tax differentials influence interstate business location is ambiguous. Until recently, business location studies in economics have ignored government expenditures or treated taxes and expenditures in an ad hoc fashion. However, two recent studies (Mofidi and Stone 1990; Helms 1985) have carefully modelled expenditures using the government budget constraint. By properly modelling the government budget constraint, the benefits of expenditures can be directly weighed against the taxes used to fund these programs. In the case of HT firms, it is plausible that benefits from greater education funding more than offset the negative impacts caused by the taxes used to fund these programs.

The effect of a state government's fiscal policy on HT firm location can be simply modelled. ${ }^{3}$ Assume firms locate in the state with the highest profits, $\pi{ }^{4}$ Firms hire labor $L$ and capital $K$. The productivity of $L$ and $K$ equals $a L$ and $b K$, where $\mathrm{a}$ and $\mathrm{b}$ are shift parameters. Assume $\mathrm{a}$ and $\mathrm{b}$ are functions of business taxes, $\mathrm{T}$, because taxes fund government expenditures that can boost productivity $\left(a^{\prime}(T) \geq 0, b^{\prime}(T) \geq 0\right)$. (Note, taxes could reduce productivity, implying $a^{\prime}<0$ and $b^{\prime}<0$.) One example is when taxes are used to fund education programs and construct infrastructure that increase labor and capital productivity. For simplicity, assume $T$ is a lump sum tax. These relationships are shown in the following equation for state $i$ and firm $j$ :

$$
\pi_{\mathrm{ij}}=\mathrm{R}(\mathrm{Q})-\mathrm{wL}-\mathrm{rK}-\mathrm{T}_{\mathrm{ij}}, \quad \mathrm{Q}=\mathrm{F}(\mathrm{a}(\mathrm{T}) \mathrm{L}, \mathrm{b}(\mathrm{T}) \mathrm{K}),
$$

where $R(Q)$ is the revenue function, and $F$ is the production function. Equation (2) shows the effect on profits from raising taxes, where $F_{L}$ and $F_{K}$ represent the marginal products of labor and capital:

$$
d \pi_{i} / d T_{i}=R^{\prime}(Q)\left\{a^{\prime}(T) F_{L L}+b^{\prime}(T) F_{K K}\right\}-1 .
$$

Depending on the productivity effects, (2) may be positive or negative. Assuming industries locate in states where expected profitability is greater, a state's 
HT employment will also be positively associated with HT profitability. ${ }^{5}$ Thus, the effects of tax and expenditure policies on employment will be directly related to those policies' effects on profits. This suggests that the sign of the derivative in (2) is also directly related to the effect of taxes and expenditures on employment.

Given the HT sector's greater skill level needs, it is likely that education expenditures will have a positive effect on HT employment through the a(T) term. Transportation costs represent a smaller share of total HT sector costs compared to other industries (Rees and Stafford 1986). This suggests that highway expenditures will have less of a positive effect on HT employment than for other industries. This relationship will be tested by comparing the impacts of education and highway expenditures for the HT sector to more aggregative levels of employment.

\section{EMPIRICAL SPECIFICATION AND DATA}

The empirical model estimates the determinants of HT employment and more aggregate employment levels. The aggregate employment specifications are used to illustrate differences in HT employment determination from employment determination in other sectors. Thus, public policy strategies designed to specifically attract HT industries can be highlighted. Other business location studies often use the number of new plants and capital investment as alternative dependent variables. Employment is chosen in this study because data is easier to obtain for the years of the study, and greater employment is the apparent goal of most economic development strategies (i.e., new plants and factories are a means to the end of greater employment). ${ }^{6}$

Data for the contiguous 48 states from 1965, 1973, 1981, and 1989 are used. The empirical specification employs first differences to control for state specific fixed effects. ${ }^{7}$ Bartik (1991) shows that if the first difference is over too "short" a time period, the resulting estimates will be a mixture of short-term and long-term effects. Bartik found that it takes about one to six years to achieve a new equilibrium after there has been a change in economic activity. Typically, most effects are felt within two years. Thus, using first differences over an eight year period should mitigate this problem.

The empirical specification for the change in employment is shown below for state $\mathrm{i}$ in period $\mathrm{t}$ :

$$
\mathrm{DEMP}_{i t}=\mathrm{a}_{0}+\mathrm{a}_{1} \mathrm{DTAX}_{\mathrm{it}}+\mathrm{a}_{2} \mathrm{DEXPEND}_{\mathrm{it}}+\mathrm{a}_{3} \mathrm{DUI}_{\mathrm{it}}+\mathrm{a}_{4} \mathrm{DZ}_{\mathrm{it}}+\mathrm{e}_{\mathrm{it}},
$$


where D represents first differences, EMP is the log of employment, and $e_{i t}$ is the error term. TAX, EXPEND, UI, and $\mathrm{Z}$ are vectors of general fund revenue variables, general fund expenditure variables, unemployment insurance variables, and demographic/labor market variables. The dependent variables are the change in the natural log of total nonagricultural employment (TOTEMP); goods producing employment (GOODEMP); manufacturing employment (MANUEMP); HT employment (HTEMP); and HT employment net of aerospace and ordnance (HTNODEF). HTNODEF is also analyzed because defense industry location may be influenced by political pressures and by historical accident. Furthermore, the end of the Cold War suggests that policies designed to attract defense industries would likely fail. Table 1 presents variable definitions and sources, and column 1 of Table 2 displays the variable means.

The government budget constraint should be modelled by controlling for all revenue and expenditure categories. If expenditure categories are omitted, it is impossible to sort out the precise effect of taxes from the separate effects of the expenditures that they fund. One category of revenues or expenditures must be omitted, or the TAX and EXPEND vectors will be perfectly collinear. Like Helms (1985), transfer payments will be the omitted category. Thus, the revenue coefficients should be interpreted as the effect of raising revenue to fund transfer payments. Similarly, the expenditure coefficients should be interpreted as the effect of increasing that expenditure category while simultaneously reducing transfer payments by an equivalent amount. A disadvantage of properly modelling the govermment budget constraint is that the revenue variables are highly correlated with the expenditure variables, resulting in inflated standard errors.

The choice of the fiscal variables is similar to Helms (1985) and Mofidi and Stone (1990), where they find that these variables have a significant influence on economic activity. To better compare across all employment specifications, all of the employment equations will employ the same independent variables.

The TAX vector contains state and local revenue variables. Like Helms (1985) and Mofidi and Stone (1990), the revenue and expenditure variables are measured as a percent of personal income. It may be preferable to use the typical effective marginal tax rate, but these rates are difficult to precisely measure. Federal grants to state and local government (FEDREV), user fees and charges (MISCREV), property taxes (PROP), and taxes net of property taxes (AGGTAX) are included in the TAX vector. A substantial element of Federal grants is transfer payment subsidies to states and localities. All things constant, the revenue variables are expected to have a negative impact on employment.

The EXPEND vector contains several state and local government expenditure categories. Education (EDUC), highway (HIGHWAY), health (HEALTH), and NETEXP are in the EXPEND vector, where NETEXP equals expenditures 
TABLE 1

Variable Definitions and Sources

\begin{tabular}{|c|c|c|}
\hline Variable & Definition & Source \\
\hline LGTOTEMP & Log of total nonagricultural employment & $\mathbf{A}, \mathbf{B}, \mathbf{C}$ \\
\hline GOODEMP & Log of goods-producing employment=(mining +manufacturing +construction) & $A, B, C$ \\
\hline MANUEMP & Log of manufacturing employment & $\mathbf{A}, \mathbf{B}, \mathbf{C}$ \\
\hline HTEMP & $\begin{array}{l}\text { Log of total high-tech employment } \\
=28+348+35+36+372+376+38(\mathrm{SICs})^{2}\end{array}$ & D \\
\hline HTNODEF & Log of total high-tech employment net of defense and aerospace & \\
\hline FEDREV & $\begin{array}{l}=28+35+36+38(\mathrm{SICs})^{2} \\
\text { General fund federal grants to state and local govermment as a percent }\end{array}$ & D \\
\hline & of personal income & $\mathbf{E}$ \\
\hline AGGTAX & $\begin{array}{l}\text { General fund state and local taxes net of property taxes as a percent } \\
\text { of personal income }\end{array}$ & $F$ \\
\hline PROP & General fund state and local property taxes as a percent of personal income & $\begin{array}{l}\mathbf{E} \\
\mathbf{E}\end{array}$ \\
\hline MISCREV & User fees and charges as a percent of personal income & E \\
\hline EDUC & State and local education expenditures as percent of personal income & E \\
\hline HIGHWAY & State and local highway expenditures as percent of personal income & E \\
\hline HEALTH & State and local health expenditures as percent of personal income & E \\
\hline TRANSFERS & State and local transfer payments as a percent of personal income & E \\
\hline NETEXP & $\begin{array}{l}\text { State and local expenditures net of education, highways, transfer payments, } \\
\text { and health as a percent of personal income }\end{array}$ & E \\
\hline NETDEBT & State and local net general fund budget surplus as a percent of personal income & $\bar{E}$ \\
\hline UIREV & Unemployment insurance fund revenue as a percent of personal income & $\bar{E}$ \\
\hline UIEXP & Unemployment insurance fund expenditures as a percent of personal income & $\mathbf{E}$ \\
\hline POPDEN & Population density in the beginning of the period, i.e., 1965, 1973, 1981 & $\bar{F}$ \\
\hline AGE65 & Percent of the population above 65 years old & $\mathrm{F}$ \\
\hline AGE17 & Percent of the population that is 17 years old or younger & $\mathrm{F}$ \\
\hline MALE & Percent of the population that is male ${ }^{b}$ & $\mathbf{B}, \mathbf{C}, \mathbf{F}$ \\
\hline UNEMP & Unemployment rate & $\mathbf{B}, \mathbf{G}$ \\
\hline WAGE & Real manufacturing wage rate deflated by the CPI $(1982-1984=100)$ & $\mathbf{A}, \mathbf{B}$ \\
\hline HSGRAD & Percent of population above 25 years old who are high school graduates ${ }^{c}$ & B \\
\hline COLLGRAD & Percent of population above 25 years old who are college graduates ${ }^{c}$ & B \\
\hline UNION & Percent of the state's nonagriculural labor force who are union members ${ }^{d}$ & $\mathbf{B}, \mathrm{H}$ \\
\hline WHITE & Percent of the population that is white ${ }^{e}$ & $\mathbf{B}, \mathbf{F}$ \\
\hline YR7365, YR8173 & $\begin{array}{l}\text { Period dummies for } 1965-1973 \text { and } 1973-1981 \text { where } 1981-1989 \text { is the } \\
\text { omitted period }\end{array}$ & N.A. \\
\hline LGHTEMP65 & Log of 1965 total high-tech employment & D \\
\hline LGHTNODEF65 & Log of 1965 total high-tech employment without defense & D \\
\hline
\end{tabular}

Notes:

'Due to County B usiness Patterns (CBP) disclosure requirements, about 18 percent of the individual two- or three-digit industries that make up the HT sector were not disclosed. CBP does provide information on the number of firms in each state within several firm size groups for each SIC. The national average firm size for each group is used to estimate the total employment of that SIC for the state. For SICs whose total state employment was not disclosed, CBP in 1981 and 1989 also provides several total employment ranges for the entire SIC industry. These ranges were also used in forming the estimate.

bor 1973, the average of 1970 and 1976 is used. For 1981, the 1980 total is used.

cFor 1965 , a weighted average of 1960 and 1970 is used. The 1973 estimate is derived from a weighted estimate of 1970 and 1980 . The 1981 estimate uses a weighted average of 1980 and 1989.

The 1965, 1973, and 1981 estimates are derived from the average state union density in 1964 and 1966, 1972 and 1974, 1980 and 1982. The 1989 estimate uses Curme et al. (1990) 1988 state union density adjusted for nonagricultural share.

'For 1965, a weighted average of 1960 and 1970 is used. The 1981 and 1989 estimates use the 1980 and 1990 figures. 
TABLE 1 (Continued)

\begin{abstract}
Sources
A. U.S. Department of Labor. Employment, Hours and Earnings: States and Areas, 1939-1982. Washington, D.C.: Government Printing Office, 1984.

B. U.S. Bureau of the Census. Statistical Abstract of the United States. Washington, D.C.: Govemment Printing Office, various years $(1966,1967,1968,1973,1974,1975,1976,1978,1982-1983,1989,1991)$.

C. U.S. Bureau of the Census. State and Metropolitan Area Data Book, 1991. Washington, D.C.: Govermment Printing Office, 1991.

D. U.S. Bureau of the Census. County Business Patterns. Washington, D.C.: Government Printing Office, various years.

E. U.S. Bureau of the Census. Government Finances. Washington, D.C.: Govemment Printing Office, various years.

F. U.S. Bureau of the Census. Current Population Reports, P20, P23, P25. Washington, D.C.: Govemment Printing Office, various years.

G. U.S. Department of Labor. Manpower Report of the President. Washington, D.C.: Government Printing Office, 1968, p. 282.

H. Curme, Michael A., Barry T. Hirsch, and David A. Macpherson. "Union Membership and Contract Coverage in the United States, 1983-1988." Industrial and Labor Relations Review 44 (1990): 5-33.
\end{abstract}

net of education, highway, health, and transfer payments. ${ }^{8}$ Finally, NETDEBT measures the net general fund surplus. I expect that highway and education expenditures will have a positive impact on employment, while the other variables' effect is less clear.

The $\mathrm{Z}$ vector includes demographic and labor market controls. Demographic variables include the percent of the population that is under 18 years old (AGE17), 65 and over (AGE65), male (MALES), and white (WHITE). High labor costs should deter employment where the real average manufacturing wage (WAGE) is included as a measure of labor costs. Labor force quality is accounted for by including the percent of the adult population that are high school graduates (HSGRAD) and college graduates (COLLGRAD). The human capital needs of the HT sector suggest COLLGRAD should have a more positive impact on HT employment than for other industries. (Herzog and Schlottmann [1991] discuss this issue.) Similarly, HSGRAD should have a more positive impact on other industries' employment than for HT. The percent of the labor force that is unionized (UNION) influences labor force quality and wages. ${ }^{9}$ A priori, the net impact of UNION on employment is unclear because unions have two offsetting impacts on employment. First, unions increase labor costs, which should reduce employment. Second, unionized work forces are potentially more productive (Freeman and Medoff 1984), resulting in greater employment.

The beginning of the period population density level (POPDEN) should control for differences between urban and rural states. Also, differences in market size, costs, and agglomeration effects will vary by population density (Helms 1985). In some specifications, the log of $1965 \mathrm{HT}$ employment will also be included. If agglomeration effects are important in the HT sector (as Rees and Stafford [1986] and Markusen et al. [1986] argue), this variable should have a 
positive impact on HT employment. Conversely, product cycle theory suggests that states with greater (lower) beginning of the period HT employment levels will also have lower (greater) HT employment growth rates, ceteris paribus. Product cycle theory implies a negative coefficient on the log of $1965 \mathrm{HT}$ employment.

The state's unemployment rate (UNEMP) and time period dummies (YR7365, YR8173) are included to control for cyclical variations. Likewise, unemployment insurance revenue and benefits (UIREV, UIEXP) are also included. Mofidi and Stone (1990) argue that controlling for UIREV and UIEXP is very important. Due to cyclical variations, UNEMP, UIREV, UIEXP, and FEDREV could be influenced by changes in employment, which would bias the coefficients (reverse causality). This possibility will be addressed below.

\section{EMPIRICAL RESULTS}

Table 2 presents the results for OLS regressions. The coefficients are multiplied by 100 so that the results are expressed in logarithmic rates of change. ${ }^{10}$ The dependent variables for columns 2-6 are the first difference of the natural $\log$ of total employment, goods-producing employment, manufacturing employment, total HT employment, and nondefense HT employment. The first nine variables are general fund variables. The revenue coefficients are generally negative, and the expenditure coefficients are typically positive. Individually, the general fund coefficients are usually insignificant. Recall, the revenue and expenditure variables are, by definition, closely linked in the government budget constraint. Thus, the proper statistical analogy is a group of zero-one dummy variables with an omitted category (e.g., monthly dummy variables). The t-statistics for the fiscal variables only show the statistical difference between that category and transfer payments. As in the case of a group of dummy variables, changing the omitted category will change the t-statistics (e.g., the t-statistics will typically be greater if FEDREV is the omitted category), but the results will remain essentially the same. Like the dummy variable group, the proper test of statistical significance is not the individual t-statistics, but an F-test for the entire group (Judge et al. 1988, chap. 11). The bottom of Table 2 shows F-statistics for the joint null regarding the significance of the nine general fund coefficients. In each case, the null is rejected at the .1 percent level, suggesting that the nine fiscal variables are jointly important. $^{11}$

Property taxes appear to have a smaller negative impact on HT employment than on the other revenue sources. One potential cause is that the HT manufacturing process relies relatively more on human capital, not plant and equipment. Hence, the base from which property taxes are assessed represents a relatively 


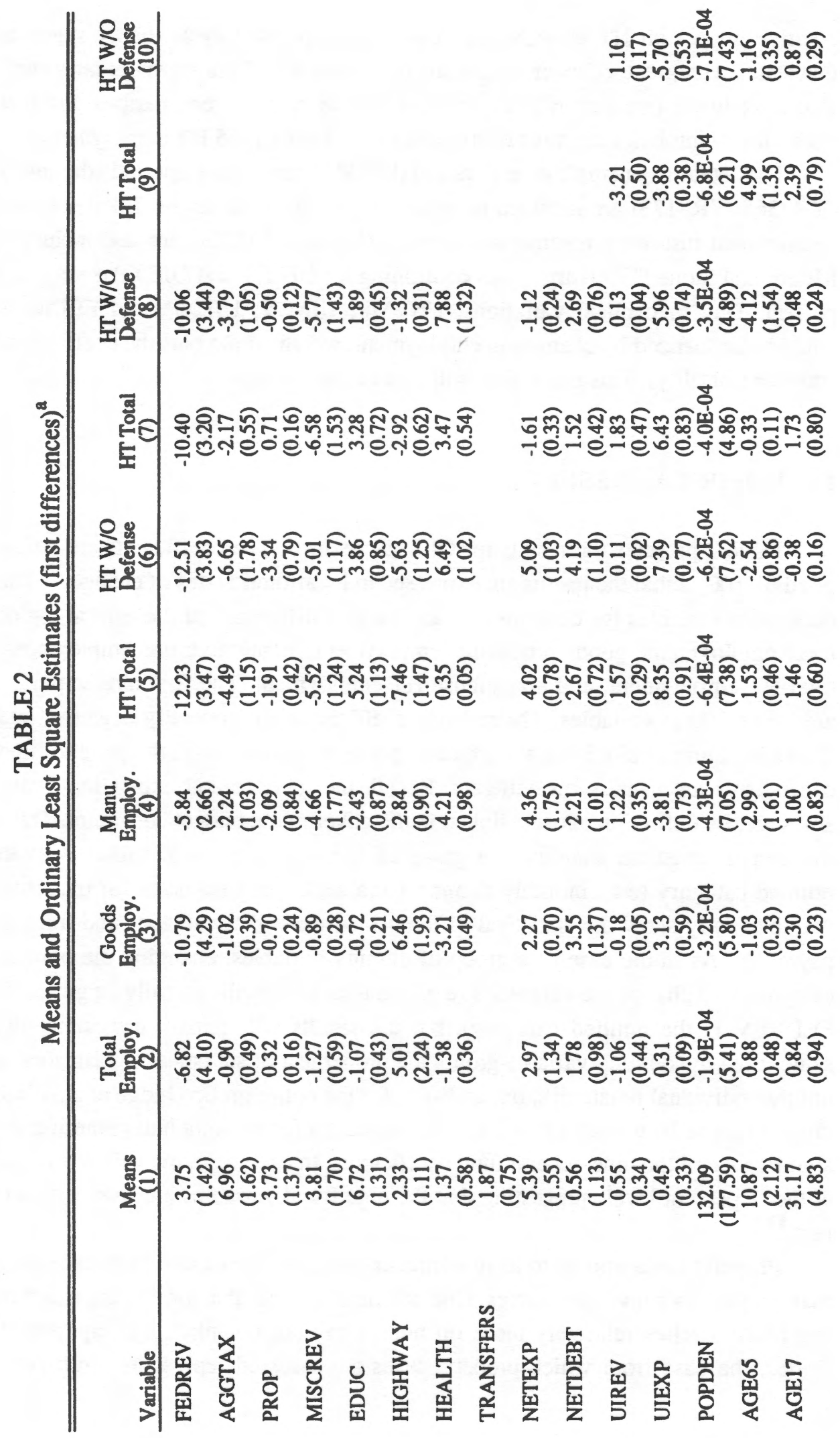




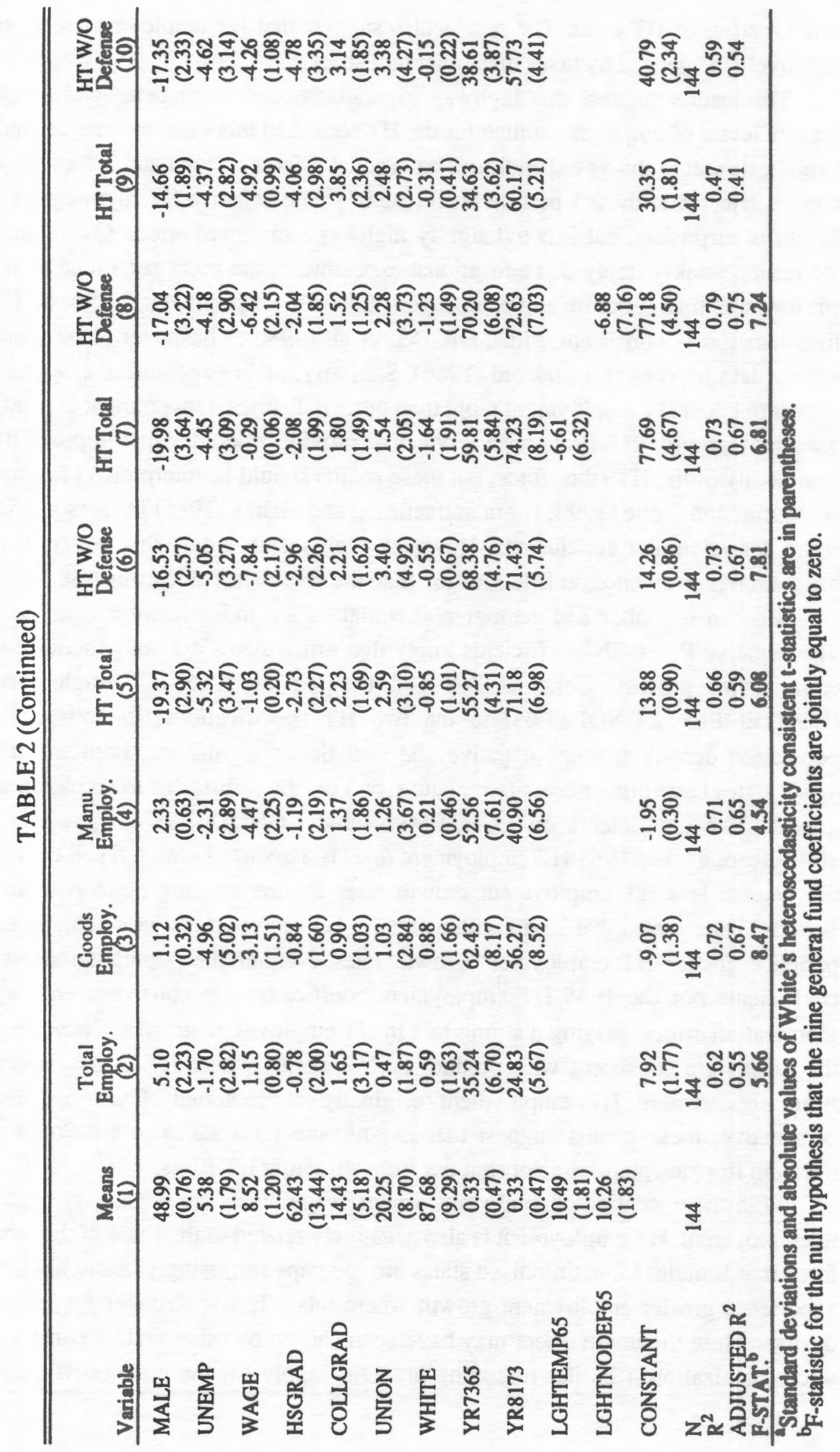


smaller share of HT costs. The results also suggest that HT employment is more negatively influenced by taxes than other industries.

The results suggest that highway expenditures are more beneficial to aggregate levels of employment than for the HT sector. In this case, the one-tail null hypothesis that highway expenditures have equal effects on total and HT employment is rejected at the 2.5 percent level $(t=2.01)$. The negative HT highway coefficient is surprising, but it could signify highway's marginal effect. Conversely, the results weakly imply that educational expenditures are more beneficial to HT employment than for more aggregate levels. Education's positive influence on HT firm location is consistent with Markusen et al. (1986), Glasmeier (1986), and survey data in Rees and Stafford (1986). Similarly, other expenditure categories appear to boost HT employment more than other industries. Government expenditures may provide HT firms with services or provide amenities that improve the availability of the HT labor force, but these results should be interpreted cautiously. Mofidi and Stone (1990) for manufacturing and Helms (1985) for personal income derive similar conclusions. However, their results imply that government has a stronger influence on firm location than the results in Table 2 suggest. ${ }^{12}$

Most of the labor and demographic variables are individually insignificant. The negative POPDEN coefficients imply that urban states are not conducive to employment growth. Columns 7-8 add the log of 1965 HT employment (LGHTEMP65, LGNODEF65) to the two HT specifications. In both cases, population density remains negative and statistically significant, implying that urban states have higher costs (e.g., land rents) or other obstacles to employment growth. The coefficients on LGHTEMP65 and LGNODEF65 suggest that a 100 percent greater $1965 \mathrm{HT}$ employment level is associated with 6.6 percent and 6.9 percent less HT employment growth rates for the ensuing eight-year time periods. Thus, states that begin with a smaller HT employment base actually experience greater HT employment growth rates. Neither the population density coefficients nor the 1965 HT employment coefficients are consistent with agglomeration effects playing a strong role in HT employment growth. Conversely, the results are consistent with product cycle theories where HT firms disperse from areas where HT employment originally concentrated. From a policy perspective, these results suggest that low-income rural states in the South or northern Rockies/plains are not shut out from attracting HT firms.

With the exception of total employment, wage levels are negatively related to employment. HT employment is also negatively related to the share of the labor force that is male. More unionized states are (perhaps surprisingly) more likely to experience greater employment growth where this effect is stronger for HT industries. Note the union effect may have been caused by other factors correlated with unionization. (Similar reasoning may also apply for the male coefficient.) 
Regardless, these results conflict with claims made by some analysts that more unionized states are more likely to suffer from a poor "business climate" and are less likely to experience economic growth. ${ }^{13}$

As expected, HT employment is positively (negatively) related to the share of the labor force that are college (high school) graduates. However, the COLLGRAD HT coefficients are only significant at the 10 percent or 11 percent level. This may be caused by a high correlation with the tax and expenditure variables (especially education). Columns 9 and 10 show that when the nine general fund variables are not included, the COLLGRAD coefficients are statistically significant at the 2 percent and 7 percent levels. The positive relationship between labor force skill and HT employment is consistent with the findings in Armington (1986) and Rees and Stafford (1986). By increasing the supply of qualified workers, education may have a further positive long-term effect (assuming the supply of college-educated labor is not perfectly elastic).

When comparing the total HT employment specification in column 5 with the nondefense HT specification in column 6 , we see that the results are qualitatively similar. In general, taxes (AGGTAX, PROP) appear to have a more negative impact on nondefense HT employment, while expenditures (except for education) have a more positive impact. Thus, to attract nondefense HT industries, taxes and expenditures must be carefully fitted to the needs of nondefense firms. Also, nondefense HT employment is more negatively related to wages, which suggests that they are more cost conscious.

Specification Issues. One empirical concem is that cyclical factors cause federal grants, unemployment insurance revenues and expenditures, and unemployment rates to be endogenously determined. A Hausman test was conducted to jointly test for the endogeneity of these four variables (see MacKinnon 1992). ${ }^{14}$ The null hypothesis that the OLS coefficients are consistent estimators is rejected at the 5 percent level for total, goods producing, manufacturing, and nondefense HT manufacturing. Conversely, the Hausman test is not significant at the 5 percent level for total HT employment. By contrast, Mofidi and Stone did not find any significant endogeneity for manufacturing, but their specification differed. For the four specifications that the Hausman test was rejected, two-stage least squares (2SLS) were estimated (not shown). The 2SLS equations treated the four cyclical variables as endogenous. The nondefense HT results are essentially the same as the OLS results. Unfortunately, the nine 2SLS general fund coefficients for total, goods producing, and manufacturing employment have the predicted signs, but the magnitude of the coefficients are implausibly large. ${ }^{15} \mathrm{AC}$ cordingly, I will not discuss these results.

Specifications were also estimated using variable levels and state fixed effect dummies. These estimates produced qualitatively similar outcomes. Moreover, 
state fixed effects are significant at the .0001 percent level, which confirms the use of first differences.

Other regressions used corporate income taxes as an additional independent variable. The null that the corporate income tax's coefficient equalled AGGTAX's coefficient is accepted at the 25 percent level in all five employment specifications. $^{16}$

Policy Discussion. These results indicate that tax and expenditure policies are jointly significant and can possibly be varied to attract HT firms. Increasing education and other expenditures beneficial to HT firms while reducing highway expenditures, appears to increase HT employment but at the expense of reducing other industries' employment. Regardless, the distribution of employment will likely shift to higher paying jobs. (Wasylenko and McGuire [1985] also found that the effects of taxes and expenditures vary across sectors.) Moreover, greater education expenditures may prove beneficial in the long run by increasing the supply of college graduates. Additionally, the results imply that a policy that cuts taxes and reduces highway and other expenditures deemed less beneficial to the HT sector may succeed. (Miller and Côté [1987] suggest similar policies.) Nonetheless, policies aimed at attracting HT firms must proceed cautiously. Particularly, HT firms appear to be more sensitive to the mix of state and local taxes and expenditures as shown by the relative size of the general fund coefficients.

The insignificance of the individual fiscal coefficients suggests that more analysis, perhaps using finer HT classifications, may be necessary before a state proceeds in enacting a HT strategy. Regardless, even carefully targeted changes in fiscal priorities may fail. In this case, even though fiscal policies jointly influence employment, the results suggest that identifying the correct mix of revenues and expenditures may be difficult. Moreover, across the board tax cuts (expenditure increases) resulting in across the board expenditure cuts (tax increases) will likely lead to mixed results at best. Therefore, a state should proceed very cautiously. Finally, a state may want to augment a tax and expenditure policy with "entrepreneurial" policies such as a "HT (or manufacturing) extension service" or an incubator program (Bartik 1991; Miller and Côté 1987). Nevertheless, policymakers should adopt a very long-term horizon for their policies. (e.g., see Miller and Côté 1987).

\section{v. CONCLUSIONS}

This study analyzes the determinants of HT employment by constructing a model of business location. Empirically, eight-year first differences over the 1965-1989 period are used to examine this issue. By carefully modelling the 
government budget constraint, this study advances HT firm location research. By comparing HT employment changes to changes in more aggregate employment levels, differences in the determinants of HT employment are highlighted for public policy analysis.

The results suggest that general fund expenditures and taxes are jointly an important determinant of HT employment. Furthermore, tailoring expenditures and taxes to the needs of the HT sector may succeed. However, the results are razor edge and can easily backfire. Thus, careful analysis must be undertaken before a state tries to attract HT firms by changing fiscal priorities. Particularly, focussing on the needs of specific HT industries (e.g., semiconductors versus scientific instruments) that are more likely to locate in the state are necessary. Future research should identify the effects of taxes and expenditures on very specific HT industries. Finally, rural states in the South or West are not dealt out of the HT game (the low-intensity states in Figure 2). Greater HT intensity may represent one avenue for these states to improve their economies, but the results may take a long time to unfold.

\section{ENDNOTES}

1. HT (and total) economic growth can originate through two avenues (e.g., Eisinger 1988). First, states attract HT firms from other states, often with tax incentives ("smokestack chasing"). Second, there is new HT firm formation using resources already located in the state. This process can be nurtured through "entrepreneurial" government policies (e.g., incubators). This study does not differentiate between the two types of HT growth.

2. HT manufacturing consists of the following SICs: 348 (ordnance), 28 (chemicals), 35 (machinery), 36 (electrical machinery), 372 (aerospace), 376 (guided missiles), and 38 (scientific instruments). Partridge (1991) discusses the differences between HT and other manufacturing industries. One important difference is that the HT sector employs more educated production and nonproduction workers. Markusen et al. (1986) and Armington (1986) define HT manufacturing industries similarly.

3. By emphasizing fiscal priorities, this study addresses a major issue in most gubernatorial races (Fosler 1988). For example, what is the appropriate level of taxation and who will pay it? One disadvantage of this focus is that it does not directly consider "entrepreneurial" policies that influence HT employment including venture capital funds or incubators. However, the overall influence of these programs appears to be modest (Eisinger 1988; Miller and Cóté 1987). 
4. For empirical analysis of the response of firm location to profits, see Rickman and Treyz (1992).

5. The effect of capital taxes on the capital-labor ratio is not explicitly considered in this model. It is possible that low capital taxes may induce the substitution of capital for labor to the degree that employment actually falls (the substitution effect dominates the output effect).

6. States could also try to attract R\&D labs, but Bania et al. (1992) show that $R \& D$ lab location is not significantly influenced by state and local policies.

7. First differences reduce omitted variable concems (e.g., invisible factors such as entrepreneurial attitudes). For example, several analysts claim that amenities are an important determinant of HT firm location. If a state's amenities are relatively constant over time, first differences reduce the need to account for amenities (i.e., amenities are a fixed effect). One problem with first differences is the ratio of measurement error variance to true variance is usually greater. Thus, first difference coefficients are more likely to be biased negatively.

8. Government expenditures may also increase HT employment by improving the quality of life (e.g., see Blakely 1989).

9. Right-to-work status is not included because it is essentially unchanged over the time period (a fixed effect).

10. For example, if the percentage of income devoted to transfer payments is reduced by 1 percent while increasing the share of personal income devoted to highway expenditures by 1 percent, total employment (column 2) rises by 5.1 percent $(5.1=100 *(\exp (5.01 / 100)-1))$.

11. Although the nine fiscal coefficients are jointly significant, many of the individual fiscal coefficients are not statistically different than transfer payments. Nevertheless, the predicted response of employment generally conforms to the results shown in Table 2 . The individual fiscal coefficients usually have their predicted signs, which indicates that we can be more confident that the effects of expenditures differ from the effects of revenues. For example, in the nondefense specification (column 6), the t-statistics for education and taxes (AGGTAX) suggest that their effects are not significantly different than transfer payments. However, the one tail null hypothesis for the equality of the two coefficients (BEDUC = $\left.B_{\text {AGGTAX }}\right)$ is rejected at the 9 percent level $\left(F_{1,120}=1.85\right)$. Regardless, the $t$-statistics suggest that policy conclusions should be interpreted cautiously.

12. Carroll and Wasylenko (1990) argue that even when incorporating the government budget constraint into the empirical analysis, the individual fiscal coefficient results may still be weaker than those found by Helms (1985) or Mofidi and Stone (1990).

13. Bartik (1991) surveys the contrasting union conclusions. Mofidi and Stone (1990) also found a positive, but statistically insignificant, union effect. 
14. The instruments for the Hausman test are the demographic variables, four regional dummies, the regional dummies interacted with the year dummies, and the percent of the nonagricultural labor force in the goods producing sector. The additional instruments are used in the two-stage least square estimates discussed below.

15. For example, if the percent of personal income devoted to transfer payments is reduced by 1 percent while increasing the percent of personal income devoted to highway expenditures by 1 percent, total employment would increase by 19.8 percent. Nevertheless, the nine 2 SLS general fund coefficients were still jointly significant at the 5 percent level. Similarly, if the nine general fund variables are treated as endogenous, the resulting 2 SLS coefficients are also implausible.

16. Specifications that added the general fund initial period levels were also estimated. The nine changes in general fund variables and the nine general fund level variables were jointly significant at the .0001 percent level. For the most part, the conclusions are essentially unchanged using this specification. Likewise, the results are essentially the same when regional dummies are added to the specifications shown in Table 2.

\section{REFERENCES}

Armington, Catherine. "The Changing Geography of High-Technology Business." In Technology, Regions and Policy, edited by J. Rees. Totawa, N.J.: Rowman and Littlefield, 1986.

Bania, Neil, Lindsay N. Calkins, and Douglas R. Dalenberg. "The Effects of Regional Science and Technology Policies on the Geographic Distribution of Industrial R\&D Laboratories." Journal of Regional Science 32 (1992): 209-228.

Bartik, Timothy J. Who Benefits From State and Local Economic Development Policies? Kalamazoo, Mich.: Upjohn Institute, 1991.

Blakely, Edward J. Planning Local Economic Development. Newbury Park, Calif.: Sage Publications, 1989.

Carroll, Robert, and Michael Wasylenko. "The Shifting Fate of Fiscal Variables and their Effect on Economic Development." In Proceedings of the Eighty-Second Annual Conference, 1989. Columbus, Ohio: National Tax Association-Tax Institute of America, 1990.

Eisinger, Peter K. The Rise of the Entrepreneurial State. Madison: University of Wisconsin Press, 1988. 
Fosler, R. Scott, ed. The New Role of American States. New York: Oxford University Press, 1988.

Freeman, Richard, and James Medoff. What Do Unions Do? New York: Basic Books, 1984.

Gerking, Shelby, and William Morgan. "Measuring Effects of Industrial Location and State Economic Development Policy: A Survey." In Industry Location and Public Policy, edited by H. Herzog and A. Schlottmann. Knoxville: University of Tennessee Press, 1991.

Glasmeier, Amy K. "High-Tech Industries and the Regional Division of Labor." Industrial Relations 25 (1986): 197-211.

Helms, L. Jay. "The Effect of State and Local Taxes on Economic Growth: A Time Series Approach." Review of Economics and Statistics 67 (1985): 574-582.

Herzog, Henry W., and Alan M. Schlottmann. "Metropolitan Dimensions of High-Technology Location in the U.S.: Worker Mobility and Residence Choice." In Industry Location and Public Policy, edited by H. Herzog and A. Schlottmann. Knoxville: University of Tennessee Press, 1991.

Judge, George G., R. Carter Hill, William E. Griffiths, Helmut Lutkepohl, and Tsoung-Chao Lee. Introduction to the Theory and Practice of Econometrics. 2d ed. New York: Wiley, 1988.

Lee, Daniel K. "A Survey of Target Industries." The Review of Regional Studies 22 (1992): 43-57.

MacKinnon, James G. "Model Specification Tests and Artificial Regressions." Journal of Economic Literature 30 (1992): 102-146.

Malecki, Edward J. "What About People in High Technology? Some Research and Policy Considerations." Growth and Change 20 (1989): 67-79.

Markusen, Ann, Peter Hall, and Amy Glasmeier. High Tech America. Boston: Allen and Unwin, 1986.

Miller, Roger, and Marcel Côté. Growing the Next Silicon Valley. Lexington, Mass.: Lexington Books, 1987.

Mofidi, Alaeddin, and Joe A. Stone. "Do State and Local Taxes Affect Economic Growth?" Review of Economics and Statistics 20 (1990): 686-691.

Newman, Robert J., and Dennis H. Sullivan. "Econometric Analysis of Business Tax Impacts: What Do We Know and How Do We Know It?" Journal of Urban Economics 23 (1988): 215-234.

Office of Technology Assessment, U.S. Congress. Technology, Innovation, and Regional Economic Development. Washington, D.C.: Government Printing Office, 1984. 
Park, Siyoung, and Lawrence T. Lewis. "Developments in the Location of Selected Computer Related Industries in the United States." Growth and Change 22 (1991): 17-35.

Partridge, Mark. "International Trade's Affect on the Labor Market." Ph.D. diss., University of Illinois-Urbana, 1991.

Rees, J., and Howard A. Stafford. "Regional Growth and Industrial Location." In Technology, Regions and Policy, edited by J. Rees. Totawa, N.J.: Rowman and Littlefield, 1986.

Rickman, Dan S., and George I. Treyz. "Industry Level Estimates of Location Responses to State Differentials in Profitability in the U.S." Unpublished paper, University of Nevada-Las Vegas, 1992.

Schellhardt, Timothy D. "Most Statehouses Likely to Weigh Aid to Small Firms." Wall Street Journal, 17 January 1992, p. B-2.

Treyz, George I. "Causes of Changes in Wage Variation Among States." Journal of Urban Economics 26 (1991): 50-60.

U.S. Department of Labor. Wages and Employment, 1990. Washington, D.C.: Government Printing Office, 1991.

Wasylenko, Michael. "Empirical Evidence on Interregional Business Location Decisions and the Role of Fiscal Incentives in Economic Development." In Industry Location and Public Policy, edited by $\mathrm{H}$. Herzog and A. Schlottmann. Knoxville: University of Tennessee Press, 1991.

Wasylenko, Michael, and Therese McGuire. "Jobs and Taxes: The Effect of Business Climate on States' Employment Growth Rates." National Tax Journal 38 (1985): 497-511. 